\title{
Corruption in Transition Economies: Cause or Effect?
}

\author{
Adisa Arapovic * \\ Craig A. Depken, II $^{*}$ \\ Mirsad Hadžikadić ${ }^{* * *}$
}

\begin{abstract}
This paper investigates the empirical relationship between corruption, economic growth, and government spending in fourteen transitioning economies from 1995-2013. We find strong evidence of bilateral Granger causation between economic growth and corruption for the full sample but weaker evidence of such a relationship for four former Yugoslav republics. We also find bilateral Granger causality between government spending and corruption but a weaker unidirectional Granger causality from government spending to corruption in four former Yugoslav republics. Our results recommend caution when assuming that corruption is purely exogenous in empirical models.
\end{abstract}

Keywords: economic growth; government spending; public corruption; Granger causality

JEL Classification: O40, D73

\section{Introduction}

A large literature connects (public) corruption with economic growth through various mechanisms. On the one hand, corruption can be thought to "grease the wheels" and enhance economic growth by minimizing bureaucratic red-tape and interference with private economic activity (see, for example, Leff, 1964, or Nye, 1967). On the

\footnotetext{
* Adisa Arapović is Vice-Rector, Associate Professor of International Finance and Economics at International BURCH University Bosnia and Herzegovina.

** Craig A. Depken, II is Professor in the Department of Economics in the Belk College of Business at UNC Charlotte.

**** Mirsad Hadžikadić is Director of the Complex Systems Institute and Professor of Software and Information Systems in the College of Computing and Informatics at the University of North Carolina at Charlotte.
} 
other hand, corruption can be thought to "sand the wheels" and reduce economic growth by extracting rents and diverting otherwise productive resources toward public officials (see, for example, Kreuger, 1974, or Tanzi and Davoodi, 1997). Previous empirical studies that make a link between corruption and economic growth often use corruption as an exogenous explanatory variable (for example, Mo, 2001, and Meon and Sekkat, 2005). However, several studies empirically investigate the correlates of corruption, suggesting that corruption might be endogenous (for example, Torrez, 2002, Gatti, 2004, and Zakaria, 2009).

The contribution of this paper is to investigate the intertemporal relationship between corruption, economic growth, and government spending for fourteen transitioning economies over the period 1995-2013. In transitioning economies, corruption might be "caused" by economic growth if there is less oversight during boom times. On the other hand, transitioning economies might experience more corruption as government spending increases. To the extent that corruption is non-trivial, it can have reverse causality on either economic growth or government spending. These relationships are tested using panel Granger causality tests.

Granger causality is most often employed on lengthy time series. Unfortunately, in the case of transitioning economies there is a paucity of reliable data before and after transitions occurred. Thus, any individual country's time series used to test Granger causality would be too short. To get around this limitation in the data, we employ panel-data Granger Causality tests developed by Hurlin (2005) and Dumitrescu and Hurlin (2012). We find that the Granger causal links between corruption, economic growth, and government spending are more nuanced than previously assumed. Our results recommend caution when assuming corruption is an exogenous regressor in empirical studies.

\section{A Brief Literature Review}

Public corruption often meets moral and legal disapproval but the direct economic impact of public corruption is ambiguous. Leff (1964) defines public corruption as one group influencing the actions of a state bureaucracy more than they otherwise would. Thus, the direct impact of corruption is not necessarily negative. For example, businesses that would otherwise be deterred from investing locally might be more prone to do so if they can influence decision-makers below the highest levels of government. Thus, corruption might extract resources to maintain a "hands off" approach to private decision making and thus corruption might be linked to higher economic growth.

On the other hand, public corruption might simply extract or divert otherwise productive resources toward public officials without an accompanying increase in economic activity. Public corruption could correspond to negative economic growth 
if sufficient resources are shifted from the private sector to a select few corrupt officials (see, for example, Kreuger, 1974, or Tanzi and Davoodi, 1997).

Public corruption is thought to harm a local or national economy if bureaucrats have the incentive and the ability to divert resources from productive to unproductive or even counterproductive purposes. A classic example is rent-seeking bureaucrats who create hold-up problems for new business or construction projects, divert public resources to family or cronies, or approve projects that benefit themselves or specific constituencies. Kreuger (1974) suggests that regulations on private economic activity can encourage competitive rent seeking by those directly affected by the regulations which leads to unambiguous reduction in social welfare. Myrdal (1968) and Mauro (1995) point out that bureaucrats have an incentive to pass more regulations than are socially optimal to increase the number of opportunities in which a bribe or other tribute can be exacted.

Ironically, the worse an economy performs the more likely a political regime will be ousted, either violently or through elections. This can reduce the time horizon of lower-level bureaucrats, if they fear they will lose their jobs sooner than later, which increases the incentives to divert more resources to themselves (Mauro, 1995).

In a mixed economy, bureaucrats have an incentive to partner with existing firms to increase barriers to entry, to raise operating costs, and to delay permissions to potential entrants to generate monopoly rents for incumbent firms from which tribute can be extracted, at the cost of less product variety and higher prices (Bliss and Tella, 1997).

Depken and LaFountain (2006) and others have shown that there are pecuniary penalties for public corruption that accrue in the area of state and national debt as higher corruption is correlated with lower bond ratings and higher interest rates, all else equal. Yet other studies show that public corruption correlates with income inequality (Gupta et al., 2002), impacts the percent of paved roads in good condition (Tanzi and Davoodi, 1997), correlates with increased school dropout rates (Gupta et al., 2000), can increase child mortality (Gupta et al, 2000), and reduces human development as measured by the United Nations (Akcay, 2006). ${ }^{1}$

In the human capital arena, as the returns to corruption increase, the competition to enter the bureaucrat class and collect available rents can provide an incentive to over-invest in political capital (Ehrlich and Lui, 1999). While public goods are ostensibly non-rivalrous and non-excludable, governments provide many goods and services that are funded by public monies, such as stadiums, highways, public housing. All such projects provide many opportunities for bureaucrats to steer business to cronies who then collect rents through higher prices and lower quality (Schleifer and Vishny, 1993). Mo (2001) finds that corruption reduces the incentive for private investment in human and physical capital.

Hodge et al. (2011) argue that the impact of corruption on economic growth is the net effect of the positive and negative effects of corruption on economic activity. 
They find that corruption has a robust net negative impact on economic growth and that the impact of corruption is positively related to governance levels and, somewhat counter-intuitively, deregulation. They point out that there does not seem to be a single policy that could be applied to public corruption in all instances and obtain the same results. This suggests that each country's experience with public corruption is somewhat unique, perhaps because of different institutions, social norms, and bureaucratic history. This intuition is supported by Meon and Sekkat (2005) who find that corruption has positive and negative influences on economic growth depending on the quality of governance in a country.

While many studies consider corruption as an exogenous regressor, several papers treat corruption as endogenous. Mauro (1995) treats corruption as an endogenous regressor in an economic growth model, using ethnolinguistic fractionalization as an instrument. Using cross-sectional data from the mid-1980s, he finds that corruption directly reduces GDP growth but also indirectly reduces GDP growth by reducing various measures of total investment. ${ }^{2}$ Torrez (2002), Gatti (2004), and Zakaria (2009) model corruption as a function of trade openness and other macroeconomic and demographic variables. They find that trade openness and human capital is associated with reduced corruption but that government expenditure and population are associated with increased corruption. These three studies are closely related to this study because we consider the possibility that corruption, economic growth, and government spending are all endogenous because they Granger cause each other.

\section{Methodology}

The concept of Granger Causality has been used to consider the relationship between time series variables. While the methodology suggested by Granger (1969) establishes causality in the broadest sense of the term, the application of the methodology has ranged from causality of sun spots and economic growth (where Sheehan and Grieves (1982) show that economic growth Granger cause sun spots) to the timeless question of which came first the chicken or the egg? (Thurman and Fisher (1988) show that it was the egg). This paper investigates the relationship between corruption, government spending, and economic growth focusing on fourteen transitioning economies starting from mid-1990s. Because of limited data availability, we utilize a panel-data Granger causality test developed by Hurlin and Venet (2001), Hurlin (2005), and Dumitrescu and Hurlin (2012), and implemented by Hoffmann et al. (2005), Hood et al. (2008), and Chen et al. (2013).

The methodology is straightforward. First, the data are tested for unit roots. Following Granger and Newbold (1977), all variables that are non-stationary are differenced until stationary. Next, a panel model is estimated with group fixed effects and a chosen number of autoregressive terms of the dependent variable (typically ranging 
from one to three). ${ }^{3}$ The parameters on the autoregressive terms are free to take any values. Finally, a chosen number of lagged values of the additional variable are also included where the parameters within any group are restricted to be the same:

$$
y_{i t}=\alpha_{i}+\sum_{k=1}^{p} \gamma_{i k} y_{i t-k}+\sum_{k=1}^{p} \beta_{i k} x_{i t-k}+v_{i t} \text {, }
$$

where $\mathrm{v}$ is a white noise error term, $\alpha_{i}$ are country fixed effects, $\gamma_{i k}$ and the and $\beta_{i k}$ can differ across countries but are assumed constant for all $k \in[1, p]$ (see Hurlin, 2005, and Hurlin and Venet, 2008). The test for panel Granger causality between $\mathrm{x}$ and $\mathrm{y}$ is a test of the null hypothesis that all $\beta_{i}=0$ for all $i$. The "unrestricted" model is that provided in equation (1) above. The restricted model sets all $\beta_{i}=0$ so that the number of restrictions equals $\mathrm{Np}$, where $\mathrm{N}$ is the number of groups and $\mathrm{p}$ is the number of lags, and the unrestricted model has NT-N(1+p)-p degrees of freedom.

Having estimated the unrestricted and the restricted models and obtaining associated sum of squared errors, the test of the null of no Granger causality is determined using the following F-distributed test statistic:

$$
F_{1}=\frac{\left(R S S_{R}-R S S_{U R}\right) / N p}{\left(R S S_{U R}\right) /(N T-N(1+p)-p)} .
$$

A failure to reject the restrictions indicates that there is no Granger causality between $\mathrm{x}$ and $\mathrm{y}$ and no further investigation is required. However, if one rejects the null of no Granger causality, the next question is whether the causal relationship is homogeneous for all groups or if some causal relationships between $\mathrm{x}$ and $\mathrm{y}$ are heterogeneous.

A test for homogeneous causality asks whether the betas are equal across all groups. This imposes Np-1 restrictions on the model. Obtaining the sum of squared errors from this restricted model $\left(\mathrm{RSS} 2_{\mathrm{R}}\right)$ allows for the calculation of the following F-distributed test statistic:

$$
F_{2}=\frac{\left(R S S 2_{R}-R S S_{U R}\right) /(N p-1)}{R S S_{U R} /(N T-N(1+p)-p)} .
$$

Failure to reject the null indicates that there is homogeneous causality across all groups, rejection suggests that one or more groups have different causal relationships between $\mathrm{x}$ and $\mathrm{y}$.

Finally, just as in non-panel Granger causal relationships, it is possible for Granger causality to be unilateral between $\mathrm{x}$ and $\mathrm{y}$, unilateral between $\mathrm{y}$ and $\mathrm{x}$, bilateral between $\mathrm{x}$ and $\mathrm{y}$, or to be non-existent between $\mathrm{x}$ and $\mathrm{y}$. To test whether $\mathrm{y}$ Granger causes $\mathrm{x}$, we reverse the roles of $\mathrm{x}$ and $\mathrm{y}$ and implement the same methodology again. We implement bidirectional tests of Granger causality between corruption and GDP growth, and corruption and government spending using one, two and three lags. 


\section{Data}

The data employed in this analysis come from two primary sources. Corruption is measured using the Transparency International Corruption Perception Index (hereafter CPI), which is a composite of public surveys of how corrupt a country is. Historically, the CPI was measured on a scale of $0-10$ but lately has been measured on a scale of 0 to 100; we maintain the 0-10 scale for the purposes of this study. In the CPI, zero would correspond to the greatest amount of corruption and a ten would correspond to the least amount of corruption. Economic growth is calculated as the annual percentage increase in annual gross domestic product as reported by the United Nations World Development Index. The amount of government spending as a percentage of national GDP is reported by the United Nations World Development Index.

The countries included in the sample are reported in Table 1 and descriptive statistics are reported in Table 2. The average annual growth rate of GDP in the broad sample of fourteen transitioning economies is $3.01 \%$ and the average corruption score is 4.696. Among the subsample of four former Yugoslav republics for which data are available, average growth rate was $2.4 \%$ and average corruption score is 3.661 (zero is most corrupt and ten is least corrupt). Those who contribute to the Transparency International corruption index view the four former Yugoslav republics as slightly more corrupt than the other countries in the sample, although the difference in the average corruption scores is less than one standard deviation. ${ }^{4}$

Table 1: Countries Included in the Sample

\begin{tabular}{|c|c|c|}
\hline Bulgaria & Hungary & Poland \\
\hline Croatia & Latvia & Romania \\
\hline Cyprus & Lithuania & Serbia \\
\hline Czech Republic & Macedonia & Slovak Republic \\
\hline Estonia & Montenegro & \\
\hline
\end{tabular}

Table 2: Descriptive Statistics

\begin{tabular}{|c|c|c|c|c|}
\hline \multicolumn{5}{|c|}{ All Countries in Sample } \\
\hline Variable & Mean & Std. Deviation & Minimum & Maximum \\
\hline GDP Growth (Annual Percentage) & 0.031 & 0.045 & -0.171 & 0.143 \\
\hline Corruption & 4.696 & 1.331 & 2.6 & 8.7 \\
\hline Government Spending (\%GDP) & 19.06 & 3.95 & $5.69^{\mathrm{a}}$ & $29.94^{b}$ \\
\hline \multicolumn{5}{|c|}{ Former Yugoslav Republics } \\
\hline GDP Growth (Annual Percentage) & 0.024 & 0.035 & -0.071 & 0.087 \\
\hline Corruption & 3.661 & 0.567 & 2.7 & 4.8 \\
\hline Government Spending (\%GDP) & 21.09 & 2.60 & 17.11 & 29.94 \\
\hline \multicolumn{5}{|c|}{$\begin{array}{l}\text { Notes: Corruption measured on a scale of } 0-10 \text { where } 10 \text { is least corrupt and } 0 \text { is most corrupt. Sample } \\
\text { comprised of } 186 \text { observations. }{ }^{\text {a }} \text { Romania in } 1999 .{ }^{\text {b }} \text { Montenegro in } 2005 .\end{array}$} \\
\hline
\end{tabular}




\section{Results}

The results of the panel-data Granger causality tests are for two sets of null hypotheses: that corruption does not Granger cause economic growth, and vice-versa, and that government spending as a percentage of GDP does not Granger cause corruption and vice-versa. These tests are undertaken for the larger sample of fourteen transitioning economies and for a subsample of four former Yugoslav republics for which we have data. The results are reported in Table 3 and Table 4.

Table 3: Panel Granger Causality Test Results

\begin{tabular}{|l|c|c|c|c|c|c|}
\hline & \multicolumn{3}{|c|}{ GDP Growth $\rightarrow$ Corruption } & \multicolumn{2}{c|}{ Corruption $\rightarrow$ GDP Growth } \\
\hline & 1 lag & 2 lag & 3 lag & 1 lag & 2 lag & 3 lag \\
\hline & & & & & & \\
\hline All Countries in Sample & $2.248^{* *}$ & 0.715 & 0.443 & $1.901 * *$ & 1.144 & 0.668 \\
\hline Former Yugoslav Republics & 0.462 & 0.235 & $4.308^{* *}$ & 0.905 & 0.504 & $1.976^{* *}$ \\
\hline & \multicolumn{7}{|l|}{} & & & & \\
\hline & $4.779^{* *}$ & 1.635 & 1.181 & $3.499^{* *}$ & 1.152 & 0.483 \\
\hline
\end{tabular}

Table 4: Homogeneous Causal Relationships

\begin{tabular}{|c|c|c|c|c|c|c|}
\hline & \multicolumn{3}{|c|}{ GDP Growth $\rightarrow$ Corruption } & \multicolumn{3}{|c|}{ Corruption $\rightarrow$ GDP Growth } \\
\hline & 1 lag & 2 lag & 3 lag & 1 lag & 2 lag & 3 lag \\
\hline All Countries in Sample & 1.696 & & & 1.982 & & \\
\hline \multirow[t]{2}{*}{ Former Yugoslav Republics } & & & $4.418 * *$ & & & 1.753 \\
\hline & \multicolumn{3}{|c|}{ Government Spending $\rightarrow$ Corruption } & \multicolumn{3}{|c|}{ Corruption $\rightarrow$ Government Spending } \\
\hline All Countries in Sample & $4.578 * *$ & & & $3.077 * *$ & & \\
\hline Former Yugoslav Republics & & & $4.839 * *$ & & & \\
\hline \multicolumn{7}{|c|}{$\begin{array}{l}\text { Notes: } \rightarrow \text { indicates direction of Granger causality. Null hypothesis is that all causal relationships are } \\
\text { homogeneous across countries. F-statistics reported. Cells in bold correspond to evidence of Granger Causality } \\
\text { in Table } 3 . * * \mathrm{p}<0.05\end{array}$} \\
\hline
\end{tabular}

There appears to be bilateral Granger causality between economic growth and corruption when using one lag but the causal link disappears when including two or three lags. On the other hand, for the former Yugoslav republics in the sample economic growth does appear to Granger cause corruption but only when including three lags. We see a similar pattern when looking at corruption Granger causing economic growth. In the broader sample of countries, a causal link appears when using 
the first lag but there is no causal relationship when including two or three lags. Corruption does not Granger cause economic growth in the four former Yugoslav republics when using one or two lags but a causal link appears when including three lags.

In the full sample, we find bilateral causation between government spending and corruption when using one lag but the causal relationship disappears when using two or three lags. In the smaller group of former Yugoslav republics, government spending does not Granger cause corruption when using one or two lags but a causal relationship appears when using three lags. In the smaller sample, corruption does not have a causal link to government spending when using one, two, or three lags.

The results in Table 3 restrict the causal relationships between any two variables to be homogeneous across the fourteen countries in the sample. Table 4 reports tests for homogeneous causal relationships for all cases where Granger causality was statistically meaningful in Table 3 . For the two cases where economic growth displayed a causal link with corruption, the evidence suggests that the causal relationships are homogeneous in the case of the broader sample of countries but heterogeneous in the case of the former Yugoslav republics. In the case of corruption Granger causing economic growth, there is weak evidence of heterogeneous causal relationships in the broader sample of countries but no evidence among the former Yugoslav republics in the sample. For the case of government spending Granger causing corruption, the evidence suggests heterogeneous causal relationships in the broader sample of counties and in the case of the former Yugoslav republics. For the case of corruption Granger causing government spending, the evidence suggests heterogeneous causal relationships among the broader sample of countries.

Our time-series evidence supports the evidence of a bidirectional Granger causal link between corruption and economic growth in the transitioning economies in our sample spanning 1995-2013.

\section{Conclusions}

In this paper, we test whether corruption, economic growth, and government spending share a Granger causal relationship in transitioning economies. The literature focusing on the impacts of public corruption on economic outcomes often assumes corruption is exogenous to economic growth or some other variable of interest. However, it is anecdotally claimed that economic growth or increased government spending in transitioning economies might encourage more public corruption. The bilateral relationships between corruption, economic growth, and government spending are investigated in this paper.

Using Panel Granger Causality tests developed by Hurlin (2005), we analyze an unbalanced panel describing fourteen transitioning economies from 1995-2013 and a subsample of four former Yugoslav republics. We analyze the relationship between 
the perceived corruption of the country as recorded by Transparency International, economic growth and government spending. We find some evidence of a bilateral Granger causal link between corruption and economic growth when using one year lag but the causal links disappear when using two or three lags. On the other hand, in the subsample of former Yugoslav republics, there is bilateral Granger causality when using three lags but not when using one or two lags.

We find evidence of bilateral Granger causation between government spending and corruption in the broader sample of countries when using one lag but not when using two or three. In the subsample of former Yugoslav republics, we find unilateral Granger causation from government spending to corruption when using three lags but not when using one or two lags.

We test for homogeneous causal relationships and find that in five of the seven instances where we find Granger causality the relationships across the various countries cannot be considered homogeneous. This suggests that the relationships between corruption, economic growth, and government spending are more nuanced than previous studies have assumed. It might be the case that corruption is related to economic growth, on average, but the relationship might be more idiosyncratic than previously thought.

The different temporal relationships between corruption and economic growth in the former Yugoslav republics invite future research. In particular, while the broader sample of countries seems to have causal relationships that are statistically meaningful when using a one-year lag to explain current year values of corruption, economic growth, and government spending, the former Yugoslav republics only show these relationship when using three lags. The source for what appears to be slower transmission mechanisms between corruption, economic growth, and government spending in this subsample of countries is an avenue for future research.

While there might be concerns that transitioning economies are particularly susceptible to public corruption because such corruption is encouraged by either economic growth or increased government spending, there is little evidence to support such an assertion beyond a single year. This does not imply that corruption is not a concern for public policy but that the transmission mechanisms appear to be relatively short term in nature. Notwithstanding high profile corruption cases that occur in transitioning economies, the results here invite comparison with the intertemporal relationships between corruption, economic growth, and government spending in more developed countries. Future research might also better distinguish between corruption and corruption opportunities in transitioning economies associated with economic growth and that associated with increased government spending.

Given the perceived and actual importance of public corruption on economic activity it is important that empirical studies provide reliable results that can help guide public debate and public policy. Our empirical results suggest that caution should be used when assuming that corruption is a strictly exogenous regressor in any empir- 
ical models. Because of the possibility of reverse causality, ordinary least squares regressions that do not control for potential endogeneity of corruption run the risk of providing biased and inconsistent parameter estimates which might influence inference and interpretation.

\section{REFERENCES}

Akçay, S. (2006), “Corruption and Human Development," The Cato Journal, 26(1), pp. 29-48.

Bliss, C. and R. D. Tella (1997), "Does Competition Kill Corruption?” The Journal of Political Economy, 105(5), pp. 1001-1023.

Chen, W., J. Clarke, and N. Roy (2013), "Health and Wealth: Short Panel Granger Causality Tests for Developing Countries," The Journal of International Trade and Economic Development, forthcoming.

Depken, C. and C. LaFountain (2006), "Fiscal Consequences of Public Corruption: Empirical Evidence from State Bond Ratings," Public Choice, 126, pp. 75-85.

Dumitrescu, E. and C. Hurlin (2012), "Testing for Granger Non-causality in Heterogeneous Panels," Economic Modelling, 29(4), pp. 1450-1460.

Ehrlich, I. and F. T. Lui (1999), "Bureaucratic Corruption and Endogenous Economic Growth," The Journal of Political Economy, 107(6), S270 - S293.

Gatti, R. (2004), “Explaining Corruption: Are Open Countries less Corrupt?” Journal of International Development, 16(6), pp. 851-861, DOI: 10.1002/jid.1115.

Granger, C. (1969), "Investigating Causal Relations by Economic Models and Cross-Spectral Methods," Econometrica, 37(1), pp. 24-36.

Granger, C. and Newbold, P. (1977), Forecasting Economic Time Series, Academic Press, New York.

Gupta, S., H. Davoodi, and R. Alonso-Terme (2002), "Does Corruption Affect Income Inequality and Poverty?" Economics of Governance, 3(1), pp. 23-45.

Gupta, S, H. Davoodi, and E. Tiogson (2000), "Corruption and the Provision of Health Care and Education Services," IMF Working Paper No. 116. Washington: International Monetary Fund.

Hodge, A., S. Shankar, D. Rao, and A. Duhs (2011), "Exploring the Links between Corruption and Growth," Review of Development Economics, 15(3), pp. 474-490.

Hood, M.V., Q. Kidd, and I. Morris (2008), "Two Sides of the Same Coin? Employing Granger Causality Tests in a Time Series Cross-Section Framework," Political Analysis, 16, pp. 324-344.

Hoffmann, R., C. Lee, B. Ramasamy, and M. Yeung (2005), "FDI and Pollution: A Granger Causality Test Using Panel Data," Journal of International Development, 17(3), pp. 311-317.

Hurlin, C. (2005), "Testing for Granger Causality in Heterogeneous Panel Data Models," Revue Economique, 56(3), pp. 799-809.

Hurlin, C. and B. Venet (2008), "Financial Development and Growth: A Re-Examination using a Panel Granger Causality Test," HAL Working Papers.

Krueger, A. O. (1974), "The Political Economy of the Rent-Seeking Society," American Economic Review, 64(3), pp. 291-303.

Leff, N. H. (1964), "Economic Development through Bureaucratic Corruption,” The American Behavioral Scientist, 8(2), pp. 8-14.

Mauro, P. (1995), “Corruption and Growth,” The Quarterly Journal of Economics, 110(3), pp. 681-712.

Mauro, P. (1997), "The Effects of Corruption on Growth, Investment, and Government Expenditure: A Cross-Country Analysis," in Corruption and the Global Economy, ed. Kimberly Ann Elliot, Institute for International Economics, pp. 83-107. 
Mo, P. (2001), "Corruption and Economic Growth," Journal of Comparative Economics, 29(1), pp. 66-79.

Myrdal, G. (1968), Asian Drama: An Enquiry in the Poverty of Nations, Vol. 2, The Twentieth Century Fund, New York.

Nye, J. S. (1967), "Corruption and Political Development: A Cost-Benefit Analysis," American Political Science Review, 61(2), pp. 417-27.

Meon, P. and K. Sekkat (2005), "Does Corruption Grease or Sand the Wheels of Growth?" Public Choice, 122(1), pp. 69-97.

Sheehan, R. and R. Grieves (1982), "Sunspots and Cycles: A Test of Causation," Southern Economic Journal, 48(3), pp. 775-777.

Shleifer, A. and R. W. Vishny (1993), "Corruption," The Quarterly Journal of Economics, 108(3), pp. 599-617.

Tanzi, V. and H. Davoodi (1997), “Corruption, Public Investment, and Growth,” IMF Working Paper No. 139. Washington: International Monetary Fund.

Thurman, W. and M. Fisher (1988), "Chickens, Eggs, and Causality, or Which Came First?” American Journal of Agricultural Economics, 70(2), pp. 237-238.

Torrez, J. (2002), “The Effect of Openness on Corruption,” Journal of International Trade \& Development, 11(4), pp. 387-403.

Zakaria, Muhammad (2009), "Openness and Corruption: A Time-Series Analysis," Zagreb International Review of Economics \& Business, 12(2), pp. 1-14.

\section{NOTES}

1 See Akcay (2006) for a review.

2 Using similar data, Mauro (1997) finds that corruption influences the composition of government spending, most obviously by reducing public expenditure on education.

3 Among the first three lags considered here, the AIC and BIC are minimized with one lag. However, we include up to three lags to be consistent with the original studies that implement this methodology.

4 We implemented Phillips-Perron panel-data unit root tests with one, two, and three lags and including a time trend. All three variables were trend stationary in each test. 